\title{
PJESME FLORIJANA ANDRAŠECA U NOVINAMA MURAKÖZ-MEDJIMURJE
}

Autor je u novinama Muraköz-Medjimurje od 1908. do 1915. pronašao pet nepoznatih pjesama Florijana Andrašeca te ukazao na problem skupljanja i obrade njegove ostavštine.

Florijan Andrašec (1888-1962) je obilježio život međimurskoga sela Dekanovca u 20. stoljeću, ali sasvim izvjesno, izvršio je snažan utjecaj i u puno širem prostoru. Bio je pučki pjesnik, pisac, glazbenik, skladatelj, kipar, slikar, sakupljač narodnoga blaga, suradnik brojnih časopisa, autor knjiga, javni radnik, čak i inovator. Sudjelovao je i bio glavni organizator u različitim udrugama i općenito se angažirao u cjelokupnom životu sela. Ostvario je veze sa mnogim istaknutim pojedincima, napose intelektualcima svoga doba u Međimurju i čitavoj Hrvatskoj. Najpoznatija je svakako suradnja Andrašeca s akademikom Vinkom Žgancem, koji je jedno vrijeme bio župnik u Dekanovcu.

Produkcija Florijana Andrašeca bila je iznimna kvantitetom - imao je nepresušne ideje, izvanredno pamćenje i stvarao je svakodnevno. Sve je rezultiralo ostavštinom koju nije lako sakupiti ni obraditi. Što je najvažnije, Andrašec je radio vrlo kvalitetno. Već kratkim uvidom u bilo koji dio njegova opusa osjećaju se snaga jednoga britkoga uma, originalnost i posebnost koje privlače pozornost, zabavljaju, ali i podučavaju, bude emocije i djeluju nadahnjujuće. Kroz Andrašecova djela cijelo selo Dekanovec i njegova okolica poprimaju sasvim drugu dimenziju. Uobičajeni seoski život i tradicija objašnjeni su na poseban način, jednostavno, a istovremeno dubinski i detaljno, otkrivaju stoljetnu mudrost naroda te tako gotovo trenutno izazivaju poštovanje publike.

S obzirom na veliki kreativni potencijal, razumljivo je zašto je Andrašec privukao pažnju mnogih radnika u kulturi, profesionalaca i amatera još za života, a posebno nakon smrti. Do danas, nešto više od pola stoljeća otkad nas je Florijan 
Andrašec napustio, objavljeno je o njemu više knjiga, članaka i znanstvenih radova. ${ }^{1}$ Zahvaljujući ponavljanjima, pa i pretiscima, može se reći da o Andrašecu danas znamo puno toga. Većina njegovih radova, osobito pisanih, poznata je javnosti, a biografski podaci solidno su obrađeni. Međutim, neka pitanja, među kojima i neka vrlo važna, presudna, još čekaju na odgovore. Jedno od njih je kada je Andrašec počeo pisati i objavljivati pjesme, što je i glavna tema ovoga članka.

Ukoliko bismo se poslužili jedinom autorskom knjigom Florijana Andrašeca „Međimurske fijolice“ zaključili bismo da je njegovo stvaranje započelo s izbijanjem Prvoga svjetskog rata u kojemu je on sudjelovao kao vojnik.

U to vrijeme bio je pozvan u 3. četu 48. carske i kraljevske pješačke pukovnije u Nagykanizsu, gdje je dobio čin razvodnika. ${ }^{2}$ Od 3. siječnja 1915. sudjeluje $\mathrm{u}$ borbama na ruskome bojištu, ali ne zadugo, jer je ranjen u nogu nakon čega se oporavljao godinama. ${ }^{3}$ Ostatak rata proveo je po bolnicama, dijelom kod kuće, a od 1917. se školovao u orguljaškoj školi u Celju.

U djelu „Međimurske fijolice“ spominje se pjesma „Mesec" napisana na ruskome bojištu i datirana s 28. VIII. 1914. kao kronološki prva. Ali, da ta pjesma nikako ne može biti početna, upućuje nas više indicija. Prije svega, „Mesec“ je pjesma napisana visokim i sasvim prepoznatljivim Andrašecovim stilom i teško je povjerovati da je on odmah na početku pisanja, bez vježbanja, bio formirani pjesnik. ${ }^{4}$ Također, pjesma je nastala u trenutku kada je Andrašec već zašao u 27. godinu života, u dob u kojoj je većina umjetnika i osobito plodnih autora već odavno započela svoj kreativni rad. Da ove pretpostavke nisu bez temelja, pokazuje objavljeni podatak Miroslava Vuka da je Andrašecova pjesma „Črez šumu“ nastala 16. X. 1910., kao i tvrdnja da je on počeo pisati još 1905 . godine. ${ }^{5}$

Prihvaćajući činjenicu da je Andrašec živio u Međimurju koje je do 1918. administrativno pripadalo Mađarskoj, prije svega se valja zapitati gdje je on mogao prezentirati ili objavljivati svoje radove, ukoliko ih je imao.

$\mathrm{U}$ Međimurju u to vrijeme postoje samo dvije tiskovine, tjednik MuraközMedjimurje i godišnjak Međimurski kolendar, koje su izlazile od 1884. do 1918. godine. Iako su oba glasila bila u funkciji dugoročnoga odvajanja stanovnika Međimurja

1 Najvažnija djela su Zvonimir BARTOLIĆ, Florijan Andrašec, međimurski pjesnik, slikar, kipar i skladatelj, ur. Franjo Božić, Njivice, otok Krk, 2009.; Miroslav VUK CROATA, ur., Hrvatske crkvene i svjetovne popijevke Florijana Andrašeca kantora u Dekanovcu u Međimurju, Zagreb, 2002.; Franjo BOŽIĆ, Florijan Andrašec: hrvatske popijevke iz Međimurja, Čakovec, 1981.

2 KERTÉSZ Elemér, Caesar De SGARDELLI, Frontharcos eszme szolgálatában, Budapest, 1942.

3 U Lista gubitaka, 307, 5, od 20. II.1915. spominje se da se Florijan Andrašec nalazi u bolnici u Brüxu u Češkoj.

4 Z. BARTOLIĆ, $n$. dj., 29.

5 Isto, 23, 31. 
od hrvatskoga nacionalnog korpusa, $u$ njima su od samih početaka pa sve do kraja objavljivana djela pučkih pjesnika koji su stvarali na kajkavskom dijalektu tipičnom za Međimurje. ${ }^{6}$ Upravo onakvom ili barem približno takvim se služio i Andrašec. Stoga je posve logično najprije pregledati spomenute naslove u potrazi za Andrašecovim pjesmama. Doista, upravo tu pronalazimo njegove prve objavljene radove uz neizostavno pitanje zašto to nitko nije primijetio sve do danas.

Razlozi za ovaj propust tek se djelomično mogu pronaći u relativnoj nedostupnosti građe. Osobito su novine Muraköz-Medjimurje većim dijelom na raspolaganju. Prije svega se čini da je za zaborav zaslužan sam Andrašec koji se nikada nije referirao na taj dio svojih objava, čak ni onda kada je objelodanio četiri svoje pjesme iz vremena Prvoga svjetskog rata. ${ }^{7}$ Mogli bismo pomisliti da su rukopisi pjesama zagubljeni nakon što su objavljeni u tisku, ali u tom slučaju ne bi dijelovi pjesme ostali očuvani, kao što je slučaj sa „Pesmom od tabora“ ili „Spomenom letošnjega božiča“. Teško je i povjerovati da bi osoba s pamćenjem poput Andrašeca u potpunosti zaboravila tekstove vlastitih pjesama.

Očito, razloge ignoriranja valja potražiti na drugim razinama. Prije svega se čini da je Andrašec smatrao da mu taj dio njegova stvaralaštva može učiniti štetu s obzirom na nacionalni predznak, koji je presudno obilježio ne samo svačiji politički već i kulturni rad u 20. stoljeću. Iako su Andrašecove pjesme objavljene u Muraközu sasvim u redu s nacionalnoga stajališta, štoviše i neočekivano korektne s obzirom na onoga tko ih je tiskao, ipak je on zaključio da ih je bolje ne spominjati. Novine Muraköz-Medjimurje dugo vremena su bile pojam mađaronstva odbojan do te mjere da čak ni oni koji su mogli potražiti u njima Andrašecove pjesme očito to nisu htjeli učiniti.

Florijan Andrašec zasigurno je imao dobru suradnju s novinarima Muraköza, osobito urednikom Margitai Józsefom, zaduženim upravo za redigiranje i prihvaćanje kajkavskih pjesama za objavljivanje. Da tome nije tako, ne bi se ta suradnja odvijala tijekom sedam godina. Lako je zamišljati da su se dva autora i osobno poznavala. Bez obzira na političke konotacije, to što je urednik Muraköza od samoga početka prihvatio Andrašeca, sasvim sigurno predstavlja za njega veliki kompliment, jer Margitai je bio najplodniji autor toga doba u Međimurju, a ujedno i vrlo strog ocjenjivač nečijega rada. ${ }^{8}$ Trebalo bi prihvatiti i činjenicu da je Andrašec Margitaia poštovao, a da je ovaj vjerojatno i utjecao na njegovo formiranje kao pjesnika. Ali, očito su se Andrašecu silno zamjerili i Prvi svjetski rat i mađarske represalije tijekom tzv.

\footnotetext{
Branimir BUNJAC, „Gramatike „međimurskoga,, jezika iz 1942.“, Filologija, 61, 68-69.

7 To su pjesme „Mesec" (28.VIII.1914.), „Želja za domom” (2.V.1915.), „Veter“ (25.V.1917.) i „Ruža“ (18. VI.1918.), objavljene u Andrašeceovoj autorskoj knjizi Međimurske fijolice.

8 Topol, VII, 1933., 2.
} 
međimurske revolucije u studenome 1918., toliko da je odlučio trajno zaboraviti na Margitaia, koji je među prvima pobjegao pred hrvatskom vojskom što je na Badnjak 1918. oslobodila Međimurje. Važno je uvidjeti da nakon povratka u Međimurje s bojišta Andrašec piše pjesme, ali nakon 1915. više ne objavljuje u Muraközu. Tu je važan za uočiti susret Andrašeca sa Vinkom Žgancom, koji mu je otvorio nove, nacionalno prirodnije puteve djelovanja, a koji je istovremeno o Margitaiu i njegovima novinama imao najgore moguće mišljenje. ${ }^{9}$

Istraživanje u novinama Muraköz-Medjimurje ubrzo je urodilo plodom, jer je pronađeno pet pjesama. Tri od njih „Pesma“, „Majuš“ i opet „Pesma“ objavljene su 1908. godine. Vjerojatno je da se radi o prvim Andrašecovim objavama uopće, jer iz naslova pjesama, bolje rečeno u pjesmama bez naslova, kao i ponešto slabijem stilu pisanja, se vidi one nisu do kraja razrađene. Treba primijetiti da je to vrijeme kada Andrašec ima tek 20 godina života pa je doista teško očekivati da postoje i neki raniji objavljeni radovi. Sve pojačava činjenica da su sljedeće dvije Andrašecove pjesme „Pesma od tabora“ i „Spomen letošnjega božiča“ objavljene u MuraközMedjimurju tek 1915. godine. S obzirom da se Florijan Andrašec ljeti 1908. oženio, vjerojatno je da pjesme objavljene te godine treba više povezivati s tim događajem nego s razlozima stvaranja pjesničke karijere. Ali, očito je da je Andrašec nastavio stvarati, jer su pjesme iz 1915. daleko kvalitetnije nego one iz 1908. godine, što ne bi bilo moguće da nije bilo stalnoga vježbanja i razmišljanja o poboljšanjima. Gdje se nalaze Andrašecovi radovi nastali između 1908.-1915. za sada nije poznato, ali gotovo je sigurno da ukoliko originali nisu sačuvani, onda su barem dijelovi tih pjesama kasnije iskorišteni i zapisani, kao što je već spomenuto.

Možda će biti moguće pronaći koju Andrašecovu pjesmu više u Medjimurskim kolendarima, ali prvo treba saznati gdje se čuvaju. U dostupnim brojevima iz 1911. i 1916. godine nema niti jedne. Međutim, ono što je sigurno jest da je upravo vrijeme Prvoga svjetskog rata bilo presudno da se Andrašec okrene radu u kulturi, kako zbog nemogućnosti da se kao invalid vrati na stari način života, tako zbog susreta sa Žgancem, a ponajviše zbog ogromnih emocija koje su u njemu probuđene na bojištu. Suočavanje sa brojnim patnjama i smrtima, uključujući i strah za vlastiti život, predstavljaju dramatičnu prekretnicu u Andrašecovoj duhovnoj preobrazbi. ${ }^{10} \mathrm{Iz}$ tih razloga u potrazi za Andrašecovim pjesmama prije 1914. godine ne treba očekivati čuda.

Pjesme objavljene u Muraköz-Medjimurju vrlo su zanimljive i zbog toga, jer pokazuju do koje mjere se njihov jezik, ali i sadržaj, tijekom vremena izmijenio. Nema nikakve sumnje da je već Margitai intervenirao u Andrašecove pjesme, kao i da ih

B. BUNJAC, $n . d j ., 72$.

10 Na sličan zaključak upućuje i Z. BARTOLIĆ, n. dj., 29. 
je on sam kasnije mijenjao i dotjerivao, ali sigurno je da su ti zapisi autentičniji od onih koji su nastali, primjerice, nakon Andrašecove smrti. Ilustracije radi „Pesma od tabora“ iz 1915. koja ima 32 strofe u knjizi objavljenoj 1981. nosi naziv „Došlo nam je vrieme " $\mathrm{i}$ ima samo deset strofa. ${ }^{11}$ Kakva je prerada pjesme nastala protekom više od šest desetljeća vidljiva je u usporednoj tablici koja slijedi, gdje prvenstveno primjećujemo da su od četiri stiha ostala samo dva.

Verzija iz 1915. godine:

Dvajstiosmog dneva tužnu tretju vuru

Žalostno javkanje ondi se je čulo.

Hodi pajdaš po me rane mi zaveži,

Izdigni me gori morti bu mi leži.

Glavicu mu primem izdižem ga više,

Al na velku žalost junak več nediše.

Zadnji put je zdehnul pogledal je k nebi,

Glavicu je spustil doli k črnoj zemlji.
Verzija iz 1981. godine:

Jafkanje se čulo: „Rane mi zaveži!

Hodi pajdaš k meni, mortim bo mi leži!“

Ja sam išel $\mathrm{k}$ njemu kaj ga zdignem gori

$\mathrm{Al}^{\prime}$ na moju žalost on vejč ne govori,

Sličan je slučaj s pjesmom „Spomen letošnjega božiča“ iz 1915. koja osim što je 1981. ${ }^{12}$ nazvana "Sveta noć je“ i bitno sadržajno promijenjena, napisana je i jezikom koji zasigurno nije Andrašecov ni dekanovski. Naime, kajkavski dijalekt je u novoj verziji u cijelosti zamijenjen štokavskim.

Verzija iz 1915.

Zakaj si tak zamišljena

Sveti večer tužna mati?

Zakaj su ti tužne oči?

Moreš mi to povedati!
Verzija iz 1981.

Što si tako zamišljena,

Sveti večer, tužna mati?

Koja bol ti srce mori,

Hoćeš li to sad kazati?

Ovakve i slične probleme mogli bi navesti još puno puta, jer se mogu pronaći i u zapisima kasnijih Andrašecovih pjesama, ${ }^{13}$ ali za to će biti potreban sustavan rad koji će nas daleko više približiti izvornom djelu.

Na kraju, objavljujemo pjesme objavljene u novinama Muraköz-Medjimurje bez intervencija, kako bi konačno i šira javnost biti upoznata s ovim do sada malo korištenim radovima dekanovskoga pučkoga stvaratelja Florijana Andrašeca.

11 F. BOŽIĆ, n. dj., 122.

12 Isto, 127.

13 Z. BARTOLIĆ, n. dj., 106. 
„Pesma“, (Muraköz-Medjimurje, br. 14/ 26. IV. 1908)

Premišljaval samsi,

V svojem tužnim srdcu

Kak ja budem živel

$\mathrm{Vu}$ velikim světu.

Da ja nĕmam dragu

$\mathrm{S}$ kom bi se raduval

Njĕna bĕla lica

Nebum več kušuval.

Ně mi je več na vim

Svetu za živeti,

Da ja nĕmam vsvojem

Srcu kaj ljubiti.

Otca mi je hladna

Vodica vmorila

Majku mi je črna

Zemlica pokrila.

I ti draga mene

V mladosti ostavljaš,

Mladoga ti mene
Vhladen grobek spravljaš.

Da ti se moj grobek

Vleti razeleni

Dojdi barem jenput

Grličica kmeni.

Na moj grobek si ti,

Žalostno poklekni

Suznimi očima,

Ovak milo reči:

Tu počivaj vmiru,

Kinč lěpe mladosti

Koj je lani vurml,

Od velke žalosti.

Ta črna zemljica,

Njemu lehka budi,

Milost božja naj ga

Na nim světu sudi.

A.F.D.

„Majuš“, (Muraköz-Medjimurje, br. 20/ 17. V. 1908)

Poslušajte draga bratja

Kaj ču vam povedat ja

Kak lěpo i vu veselju

Nam je došla doba ta.

Sad je došlo protuletje

To več anda znamo svi

Da se vsakim vrtu ruža

$\mathrm{Vu}$ majušu čerleni.

Zato anda draga bratja,

I sve mile sestrice,

Ja vam oču podeliti

Vuzmene pisanice.

Tak najpredi vi junaki
Pisanice dajem vam,

I veselje v ovoj dobi

Sveg srca želim vam.

A vi mlade devojčice

Koje para nĕmate,

Več se najte žalostiti,

Pisanica vaša je.

I vi bute draga bratja,

Pisanicu dobili,

Koji ste vu hižni zakon

More biti stupili.

Vi snešice, šogorice,

Pisanica vaša bu, 
Veselte se i radujte,

Vu mesecu majušu.

Vi starčeki i starice

Pisanicu dam i vam

Sveti Jožef obranitelj

Neka bu na pomoč vam.

Tak i vi mala dečica,

Koja v školu hodite

Jednu lĕpu pisanicu

Vu majušu dobite.

Majuš mesec kak si lěpi,

Kak si lepi cvetači?
Po šumicaj i po gmajni

Mi spěvaju ftičeki.

I ribice ke vu vodi

Gori doli plavaju,

I vu ovoj lĕpoj dobi,

Veselo se igraju.

Sve zverine i ftičice

I črveki pod zemljum

$\mathrm{V}$ ovim majušu mesecu

Vesele se med sobom.

Složil: Andrašecz Florian.

„Pesma“, (Muraköz-Medjimurje, br. 24/ 14. VI. 1908)

Leto nam jezero

Devetsto i osmo

Ali moje srce

Zato bu žalostno.

Komaj si ja čekam

Lĕpo protuletje,

Kaj se razveseli,

Moje tužno srce.

Onda si bum trgal

Šipkove ružice,

I na prsa metal

Modre fijolice.

$\mathrm{V}$ šumicu zelenu

Se budem ja šetal,

Svakoformu ruže

Bum na prsi metal.

Šumica zelena

Potrpi mi hlada

Da me bu čekala

Grličica draga.

Da bi ja bil domaj

To cvatuče leto

Imel bi veselje

Draga na tim svĕto.
Ali da bum išel

Vu Nemšku zemlicu

Domaj bum ostavil

Dragu gerličicu.

Sprevajala budeš

Mene ti do cuga;

Kaj mi srce mine

Malo ova tuga.

Budem te ja dragi

Golub sprevajala,

I za tobom se bum

Navĕka plakala.

De mašina bliže

Ktej golub dohaja,

Moje tužno srce

$\mathrm{Vu}$ žalosti zdvaja.

Da mašina gene

Moje srce zdehne

Golubek ljubljeni

De ti sunce zajde.

Meni sunce zajde

$\mathrm{Vu}$ Nemškim orsagu

De nam ljubil svoju

Gerljičicu dragu. 


\section{A. F. D.}

„Pesma od tabora“, (Muraköz-Medjimurje, br. 7/14. II. 1915.)

Došlo nam je leto tuge i žalosti,

Ne je moči žalost spisati za dosti.

Jezero devetsto štirnajstog leta

Vnoga majka v tugi živela je sveta.

Augustuš meseca deneka drugoga

Ostavil sam para k srcu povoljnoga.

Moral sam oditi po širokim svetu,

Da je svaki vrtek bil v najlepšem cvětu.

Dvajsetoga dneva Augustuš meseca

Došla mi je žalost do mojega srca.

Moral sam staviti Megjimurje malo

Gde je v sakim grmu lĕpo svetje cvelo.

Cesarska nas banda k cugu sprevodila

Gospoda su lěpo cuga okinčila.

Zastave su bile nared nametane

Cvetje navezano na obedve strane.

$\mathrm{Ob}$ dvanajsti vuri cug prične gibati,

$\mathrm{Na}$ to je morala banda za igrati.

Čulo se vikanje zbogom dragi sini, Samo verni budte svojoj domovini!

Štiri dni i noči mi smo se pelali,

Pri ruski granici s cuga doli stali.

K regementu svomu jesmo maširali,

Ki su pri Lublinu tabora držali.

Dvajstiosmog dneva tužnu tretju vuru

Žalostno javkanje ondi se je čulo.

Hodi pajdaš po me rane mi zaveži,

Izdigni me gori morti bu mi leži.

Glavicu mu primem izdižem ga više,

Al na velku žalost junak več nediše.

Zadnji put je zedhnul pogledal je k nebi,

Glavicu je spustil doli k črnoj zemlji.

Pri Lublinu strašno štuki su pokali,

Šrapneli, granati na nas su padali,

Jen se ovdi zruši, drugi tam opadne,

Sunčece rumeno već ga $v$ grobu zajde. 
Groba smo skopali, kre šume zelene,

Venca smo mu spleli koji nepovehne,

Ov bu venec spomen megjimurskom sinu,

Koj je verno branil svoju domovinu.

Križa napraviti z bora zelenoga,

Koj bu znamenuval pokoja večnoga,

Stravicom zelenom groba smo pokrili,

Suznimi očima smo ga ostavili.

Ostala je vnoga majka prez sineka,

I vnoga dečica prez svoga japeka.

Vnoga devojčica para je zgubila,

Vnoga draga svega, koga je ljubila.

Mamica ljubleni radi bi vi znali,

Gde sam ja v taboru med dvema gorami,

$Z$ obedveju strani visoka planina,

Drugo se ne vidi nebeska visina.

Ne je ovdi ćuti ftičke popěvati,

Nit po vrtu lěpe ružice cvetati,

$\mathrm{Oj}$, ti tužna zemlja nisi vredna toga,

Da je vnogi junak našel groba svoga.

Vnoga draga sebu žalostno plakala,

Kaj za svoga para grobek nebu znala,

Nebu mogla draga groba pohajati,

Na dušniden na jem svečicu vužgati.

Naj se samo moli za svojega para,

Koj je verno branil svetloga cesara,

Maj mu zadnjič reče ovo bu ti znamen,

Lehka ti zemljica pokoj večni amen!

Spisal: Andrasecz Florián, vojnik i cipészmester, Dekánfalva. 
„Spomen letošnjega božiča“, (Muraköz-Medjimurje, br. 52/ 26. XII. 1915)

Světa noč je, bor na stolu

Kre njeg tužna majka sedi,

Sveti večer obstrli su,

Nočne zvězde traki blĕdi.

Zakaj si tak zamišljena

Sveti večer tužna mati?

Zakaj su ti tužne oči?

Moreš mi to povedati!

Tužna majka odgovara:

„Tam vu gorah i planina,

Usred snega vu taboru,

Duša gledi moga sina!"

„Draga majka, znam je vezda,

Kud miseli vaše hode,

Molite se, noč je světa,

Veselje vam nazaj dojde!"

A pri meši, pri polnočnoj,

Pred oltarom tiho moli,

Kak da iz jaselci sveti,

Nešči tiho joj govori:

"Zmisli se ti majka denes!"

- Govori njoj božje děte,

Ja sam, hotel ostaviti

Modrog neba, dvore světe."

"Da nadvladam dušmanina",

Došel sam vu suzne doli,

Da odkupim duše vaše

Svojom krvjom, v svojoj boli"

Večnu sreču i blaženstvo

Zamenil sam s mukom križa,

Znaš ti majka! da iz križem

Steza v nebo je najbliža.

Svoju dužnost verno zvršit,
Ti plakati nebi smela.

Světa dužnost domovinska

Teb je tvoga sina zela.

Za svoj dom i kraljev tronuš

Stoji on na snežnoj straži,

Svetel mesec naj mu sveti,

Tihi deždjek naj ga snaži.

Tak se moli tužna mati

Blagoslov pošilja sinu,

Da bi se povrnul nazaj

V svoju milu domovinu.

Neznem denes gde je kam je?

Naj bu Bože tvoja volja!

Na to nešči stupi v hižu,

Eto lista z bojnog polja.

I počita sinov pozdrav,

Něma ona prvlje mira.

Prime v ruke ona lista,

I s veseljem ga odpira.

- Primite od mene pozdrav

Roditelji moji mili,

Da bi ove světe dane

$\mathrm{Vu}$ veselju sprevodili.

- Ja se ovdi dobro čutim,

Kak da bi bil domaj s vami,

Daj Bog, da veseli budu.

I mej ovi sveti dani.

- Dok bum branil domovinu,

Bi veseli dani bili,

I da bi se barem $\mathrm{k}$ letu

Ov den skupa veselili!

A.F., Dekanfalva. 


\section{IZVORI}

1. Lista gubitaka

2. Muraköz-Medjimurje

3. Topol

\section{LITERATURA}

1. Florijan ANDRAŠEC, Međimurske fijolice, Prelog, 1953.

2. Zvonimir BARTOLIĆ, Florijan Andrašec, međimurski pjesnik, slikar, kipar i skladatelj, (uredio: Franjo Božić), Njivice, otok Krk, 2009.

3. Franjo BOŽIĆ, Florijan Andrašec: hrvatske popijevke iz Međimurja, Čakovec, 1981.

4. Branimir BUNJAC, „Gramatike „međimurskoga,, jezika iz 1942.“, Filologija, 61, Zagreb, 2013.

5. KERTÉSZ Elemér, Caesar De SGARDELLI, Frontharcos eszme szolgálatában, Budapest, 1942.

6. Hrvatske crkvene i svjetovne popijevke Florijana Andrašeca kantora u Dekanovcu u Međimurju (uredio: Miroslav VUK CROATA), Zagreb, 2002.

\section{SAŽETAK}

\section{PJESME FLORIJANA ANDRAŠECA U NOVINAMA MURAKÖZ-MEDJIMURJE}

Autor je u novinama Muraköz-Medjimurje u razdoblju od 1908. do 1915. pronašao pet do sada nepoznatih pjesama Florijana Andrašeca, čuvenoga pučkog pjesnika iz Dekanovca. Istražuje razloge zašto su ove objave, koje kronološki odgovaraju najranijim poznatim Andrašecovim radovima, bile zanemarene. Ukazuje na problematiku sakupljanja i obrade Andrašecove ostavštine kroz sadržajnu i jezičnu analizu pjesama koje na kraju članka donosi u izvornome obliku.

Ključne riječi: Međimurje; Dekanovec; Florijan Andrašec; pučko pjesništvo. 


\section{SUMMARY}

\section{FLORIJAN ANDRAŠEC'S POEMS IN MURAKÖZ-MEDJIMURJE NEWSPAPER}

The Autor has found in newspaper Muraköz-Medjimurje, in time from 1908. to 1915. five up until now unknown lyric from Florijan Andrašec, the famous folk poet from Dekanovec. He is researching why were these issues, that chronologically correspondent to the earliest work of Andrašec, neglected. He infers to the matters of collecting and working on Andrašec's herritage through the content and language analysis of the lyrics that he brings up at the end of the article in their authentic form.

Key Words: Međimurje; Dekanovec; Florijan Andrašec; folk poetry. 